\title{
DUCHOWNI PATROLOGOWIE SŁOWACCY
}

W ubiegłym roku ukazał się w Bratysławie na Słowacji ciekawy obszerny Stownik słowackich osobistości kapłańskich [Lexikon katolických kňazských osobnosti Slovenska (= LEKKOS), red. Julius Pašteka i zespół autorski, przedmowa Kadinal Ján Chryzostom Korec, Bratislava 2000, LUČ, vydavateské družstvo, ss. XII, nlb. 4, kol.1550, nlb. 2, LIV, nlb. 6, ilustr], będący kopalnią informacji o Kościele i teologii tego kraju. Jest on niewątpliwie związany z wielkojubileuszowym rokiem 2000, choć na rynku księgarskim ukazał się dopiero końcem marca 2001 roku; jako dzieło godne dwóch chronologicznych wydarzeń kończącego się XX stulecia nie był jednak żadnym zaskoczeniem. Przeciwnie, od chwili ujawnienia jego projektu ${ }^{1}$ stawał się publikacją niecierpliwie wyczekiwaną, przyjętą z wielką i powszechną radością. Nas interesują w nim patrologowie słowaccy oraz ich zainteresowania.

Przy pomocy indeksu nazw osobowych, umieszczonego przy końcu Leksyko$n u$ : patrolog-historyk, a szczególnie patrolog-bibliograf, znajdzie informacje o imieniu Ojca Kościoła lub chrześcijańskiego pisarza. Umieszczony tam odsyłacz kolumnowy umożliwia odnalezienie w tekście informacji dotyczącej samej osoby, a w drugim rzędzie nazwiska i imienia tego spośród słowackiego kleru, dla kogo dany Ojciec Kościoła albo pisarz chrześcijański był przedmiotem jego zainteresowań, studium lub publikacji. Z bogatego grona osobistości patrystyki, duchowni słowaccy ukazani w Leksykonie, poświęcili swoje zainteresowania trzynastu Ojcom i trzem pisarzom chrześcijańskim (Boecjuszowi, Minucjuszowi Feliksowi i Orygenesowi). Spośród zaś Ojców ich zainteresowanie wzbudzili Święci: Ambroży, Atanazy, Augustyn, Cyprian, Cyryl Jerozolimski, Grzegorz z Nazjanzu, Grzegorz Wielki, Hieronim, Ignacy Antiocheński, Jan Złotousty, Justyn, Korneliusz i Leon Wielki.

${ }^{1}$ Autorem projektu był Prof. PhDr Julius Pašteka, DrSc. Ujawnienia projektu dokonano w lipcu 1995 roku, a w następnym - wewnętrzna redakcja Wydawnictwa LUČ rozpoczęła pierwsze prace ze stopniowo rozszerzającym się zespołem autorów haseł i współpracowników, który został ograniczony do osób. Redakcyjne przygotowane do druku materiały Leksykonu liczyły 2956 stron. 


\section{1. ŚW. AMBROŻY}

a). Sirovič František (ur. 16.02.1920 - Ždaňa, powiat Košice-okolie.), werbista misjonarz, profesor filozofii. Nauki gimnazjalne pobierał w Koszycach i w Lewoczy (1932-1940). W roku 1940 wstąpił do werbistów. Filozofię studiował we Wiedniu (1942-1943) i w Nitrze (1943-1944). Studia teologiczne odbył u jezuitów w Banskej Bystrzycy (1944-1945) i w Rużomberku (1945-1946). Po święceniach kapłańskich (01.09.1946) studium teologii zakończył zdobyciem licencjatu (1947) w Uniwersytecie Gregoriańskim w Rzymie, na podstawie pracy: Tajemnica Kościoła według św. Ambrożego ${ }^{2}$. Oprac. V. Judak, LEKKOS, kol. 1239.

b). Coppa Giovanni (ur. 09.11.1925 - Alba, prowincja Cuneo, Włochy), arcybiskup, Nuncjusz Apostolski, historyk i pisarz religijny. Po studiach filozoficznych i teologicznych w Alba przyjął święcenia kapłańskie (02.01.1949 r.). Studia specjalistyczne kontynuował w Mediolańskim Uniwersytecie Katolickim Serca Jezusowego i tam też się habilitował. Należy do wybitnych znawców życia i dzieł św. Ambrożego. Artykuły o nim publikował w czasopismach: „Latinitas”, „Ecclesia”, „Duchovný pastier”, „Fermentum” i w dzienniku „L'Osservatore Romano”. Swoje specjalistyczne studia publikował w języku włoskim. Oprac. D. Dian, LEKKOS, kol. 181.

\section{2. ŚW. ATANAZY}

a). Lucký Metod Ondřej (ur. 21.11.1919 - Trstená, powiat Tvrdošin), dramaturg, tłumacz, redaktor. Szkołę podstawową i pierwsze lata gimnazjalne ukończył w miejscu pochodzenia. W Trnawie wstąpił do zakonu franciszkanów (25.08.1936). Świadectwo dojrzałości zdobył w zakonnym gimnazjum w Malackach (1941). Studia teologiczne ukończył w Instytucie zakonnym w Żylinie. Tam też przyjął święcenia kapłańskie (19.08.1945). W jego przekładowym dorobku znalazły sobie miejsce: Antologia patrystyczna ${ }^{3}$ i atanazjański Żywot św. Antoniego pustelnika ${ }^{4}$. W roku 1954 opuścił zakon przechodząc w szeregi duchowieństwa diecezjalnego. Oprac. R. Hudec, LEKKOS, kol. 836-837.

b). Wagner František, (ur. 14.08.1675 - Wangen w Niemczech, zm. 08.02.1746 - Wiedeń), jezuita, historyk, geograf, filolog, hagiograf. Do zakonu jezuitów wstąpił we Wiedniu (10.10.1690). Studia filozoficzne (1694-1696) odbywał w Sztajerskim Hradc. Tam też ukończył (1705) studia teologiczne, które zaczynał (1702) w Wiedniu. Jego bogaty i znaczący dorobek pisarski obejmuje 26 dzieł opublikowanych drukiem. Chociaż do najważniejszych zalicza się jego: Introductio in historiam biblicam (Wiedeń 1729-1732) i łaciński słownik frazeo-

\footnotetext{
2 Tajemstvo Církvi podl'a sv. Ambróza.

3 Šlová Otcov, Prešov 1947.

${ }^{4}$ Atanáz sv., Život blahoslaveného Antona, Trnava 1950.
} 
logiczny ${ }^{5}$, to patrologa zainteresuje jego Vita magni theologi s. Athanasii episcopi Alexandrini (Wiedeń 1707). Oprac. J. Slaný, LEKKOS, kol. 1491n.

\section{3. Św. AUGUSTYN}

a). Ferenčik Jan (ur. 01.01.1888 - Kežmarok, zm. 09.11.1950 - Leopoldów, pow. Hlohovec, pochowany w Keżmarku) pisarz religijny i publicysta, teolog, pedagog, polityk, poseł. Gimnazjum zaczynał w Keżmarku, a kończył w Rożniawie. Studia teologiczne odbył w Spiskiej Kapitule, a kościelno-prawne na Wydziale Teologicznym uniwersytetu w Budapeszcie. Święcenia kapłańskie przyjął 01.06.1911 roku. Pracę duszpasterską zaczynał w Liptowskiej Łużnej. W latach 1912-1917 pracował w Ruzomberku, gdzie nawiązał bliskie kontakty z wielką osobistością Słowacji - ks. Andrzejem Hlinką. W roku szkolnym 1917/1918 został mianowany katechetą w Państwowej Wyższej Szkole dla Dziewcząt w Lewoczy. Po uzyskaniu doktoratu z prawa kościelnego (1918), w listopadzie następnego roku został profesorem Rzymskokatolickiego Seminarium Nauczycielskiego w Spiskiej Kapitule. Z nominacji biskupa spiskiego Jana Vojtaššaka (1923-1926) prowadził w tutejszym Wyższym Seminarium Duchownym wykłady z teologii. W latach 1926-1931 pelnił funkcję dyrektora Głównego Biura Katolickiego w Bratysławie. W roku 1931 powierzono mu funkcję rektora Wyższego Seminarium Duchownego w Spiskiej Kapitule oraz wykłady z prawa kościelnego i historii Kościoła. Po śmierci Andrzeja Hlinki objął po nim parafię w Rużomberku. Po ukonstytuowaniu się państwa słowackiego rozwinął szeroką działalność polityczną. W pierwszych wyborach do parlamentu, wyborcy powiatu Rużomberok powierzyli mu mandat poselski. Oprócz tego w Rużomberku pełnił funkcję przewodniczącego miejskiego oddziału Słowackiej Hlinkowej Partii Ludowej. W latach 1939-1945 był posłem sejmowym Republiki Słowackiej. W roku 1945 został aresztowany, a po procesie politycznym został skazany na długoletnie ciężkie więzienie, które odbywał w Leopoldowie. W czasach pierwszej Czechosłowackiej Republiki przez 12 lat był redaktorem jednego $\mathrm{z}$ najstarszych i najpopularniejszych czasopism katolickich - „Svátá rodina” i czasopisma „Rozvoj”. Wśród teologów uważany był za konserwatystę. W jego bogatym dorobku publikacyjnym trzeba odnotować artykul: Sv. Augustin, obraz z jeho života opublikowany w czasopiśmie „Kultúra” 3 (1931) č. 2. Oprac. J. Letz, LEKKOS, kol. 333-335.

b). Hlinka Anton (ur. 31.10.1926 - Valaška Belá, pow. Prievidza), salezjanin, publicysta, teolog, filozof. Szkołę podstawową i gimnazjum ukończył w Poważskiej Bystrzycy. Do Zgromadzenia Salezjanów wstąił w roku 1944. W roku 1951 wyemigrował za granicę i tam stopniowo w Turynie, Rzymie i Wiedniu studiował filozofię, teologię i psychologię. Święcenia kapłańskie

${ }^{5}$ Universalatinae corpus phraseologiae congestum A.P. Francisco Vágner... linguis hungarica, germanica et slavica locupletatum, ed. tertia, Augusburg 1718. 
przyjął 01.07.1955 roku. W latach 1958-1967 prowadził wykłady w seminariach salezjańskich w Wiedniu, Kolonii i Katanii. Na podstawie pracy: Die theologischen Grundlagen der Bildungslehre Theodor Litts w Rzymie (1961) uzyskał doktorat z filozofii. Od roku 1971, jako redaktor programów religijnych w języku słowackim, pracował w rozgłośni radia Wolna Europa i Głos Ameryki. W roku 1991 powrócił do Słowacji. W tym też roku założył Słowacką Akademię Katolicką, której został pierwszym rektorem. W roku 1995 habilitował się z teologii i został docentem na Cyrylo-Metodejskim Wydziale Teologicznym Uniwersytetu w Bratysławie; w roku 1997 mianowano go profesorem filozofii na Uniwersytecie Konstantyna Filozofa w Nitrze. Na jego dorobek pisarski złożyło się 30 publikacji książkowych, wśród których pokaźną część stanowią przekłady, a między nimi słowacki przekład Augustynowych Wyznań. Oprac. Jan Letz, LEKKOS, kol. 491-493.

c). Kereškéni Adam (ur. 24.01.1713 - Komarno, zm. 01.02.1777 - Kluż w Rumunii) - jezuita, uniwesytecki profesor, tłumacz. Do Towarzystwa Jezusowego wstąpił 14.10.1728 roku. Studia filozoficzne odbył w latach 1732-1734 w Trnawie. Lata 1735-1739 spędził w jezuickich szkołach średnich jako nauczyciel gramatyki i przedmiotów humanistycznych. Teologię (w latach 1739-1742) studiowal w uniwersytecie wiedeńskim. W latach 1745-1748 jako profesor uniwersytetu trnawskiego wykładał etykę i filozofię, a przez jeden rok (1751) prowadził zajęcia z teologii moralnej w Eger, jako profesor tamtejszego węgierskiego uniwersytetu. Dwukrotnie też pełnił obowiązki dyrektora drukarń: Akademickiej w Koszycach (1767-1768) i w Klużi (1773). Dla śledzących literaturę o tematyce patrystycznej, nie powinno ujść uwagi jego opracowanie żywota biskupa z Hippony: Agostonnak megtérése (Trnawa 1758). Oprac. J. Slaný, LEKKOS, kol. 656.

d). Litwa Alojzy (ur. 20.06.1912 - Mikszowa, pow. Bytcza, zm. 02.11.1998 Iwanka nad Dunajem, pow. Bratysława), jezuita, teolog, pedagog, pisarz religijny. Gimnazjum zaczynał w Trnawie, ukończył je w roku 1933 w miejscowości Kláštor pod Znievom. W międzyczasie w roku 1928 wstąpił do Towarzystwa Jezusowego. Studia filozoficzne (1933-1936) odbył w angielskim Jersey, teologiczne zaś w roku 1937 zaczynał w Chieri, a od 1938 aż do roku 1941 kontynuował w holenderskim Velkenburgu. W roku 1939 przyjął święcenia kapłańskie. Po ukończeniu studiów teologicznych, w latach 1941-1946 początkowo w Banskiej Bystrzycy a później w Rużomberku, prowadził dydaktyczne zajęcia z teologii. Specjalistyczne, dopełniające studia teologiczne odbył w Rzymie w latach 1947-1949. Po powrocie do kraju wykładał teologię w jezuickim seminarium w Trnawie. Od kwietnia 1950 do maja 1968 r. był kolejno internowany w Jasowie, Podolincu, Żeliwie i Kralikach, a po skazaniu, więziony w Ostrawie, Banskiej Bystrzycy i Waldicjach. Po powrocie $z$ więzienia pracował duszpastersko jako kapelan sióstr Satmarek w Kirti. Z niewielkiego dorobku pisarskiego, patrologów-bibliografów zainteresuje jego monografia: Teologia św. Au- 
gustyna (Trnawa 1991) i jej wznowienie z roku 1993. Oprac. Jan Letz, LEKKOS, kol. 828.

e). Marko Jan (ur. 12.02.1915 - Zazriwa, pow. Dolny Kubin, zm. 1977 Podoliniec, pow. Stara Lubownia), pisarz religijny, teolog, filozof, tłumacz. W latach 1936-1941 studiował teologię w Wyższym Seminarium Duchownym w Spiskiej Kapitule. Święcenia kapłańskie przyjął w 1941 r. z rąk Sługi Bożego biskupa Jana Wojtaššaka. Po krótkiej pracy duszpasterskiej w parafii Zubrohlava, w roku 1942 powierzono mu obowiązki kurialnego archiwisty w Spiskiej Kapitule i profesora religii w gimnazjum w Spiskiej Nowej Wsi. W latach 19441945 studiował na Wydziale Teologicznym Uniwersytetu w Bratysławie. W latach 1946-1950 pracował duszpastersko w parafii Dolny Kubin początkowo jako wikariusz, a później jako jej proboszcz. W roku 1950 został internowany i skazany na 13 lat pozbawienia wolności. Po odbyciu niesprawiedliwie wymierzonej kary, władze komunistyczne nie pozwoliły mu wrócić do zajęć duszpasterskich i był zmuszony pracować jako świecki. Ostatnich dziesięć lat swego życia spędził w Podolińcu, gdzie pracował duszpastersko jako proboszcz i dziekan. Z łaciny przełożył na język słowacki apologię Minucjusza Feliksa: Octavius (Trnawa 1950). Jako publicysta od roku 1943 był redaktorem satyrycznego czasopisma „Voš”6. Swoje zaś artykuły publikował w czasopismach: „Katolické noviny” i „Kultura”. W tym ostatnim zrecenzował monografię L. Bertrand: Sv. Augustin 7 . Oprac. Jan Letz, LEKKOS, kol. 877.

f). Skyčak Franciszek ml. (ur. 17.02.1899 - Klin, pow. Namestowo, zm. 05.01.1945 - Spiska Kapituła, pow. Lewocza), neoscholastyczny filozof, teolog, publicysta i pedagog. Nauki gimnazjalne zaczął w Jozsefvárosi (Węgry), kontynuował je w Małym Seminarium w Rożniawie, a ukończył w 1914 r. w rodzinnym Namestowie. Potem wstąpił do węgierskiego Seminarim Duchownego w Spiskiej Kapitule, skąd na studia teologiczne przeniósł się do Budapesztu, a w końcu do Pragi (1918-1920). Pozostając tam do roku 1921 stał się współzałożycielem Związku Katolickich Studentów Słowackich (POVAN). Święcenia kapłańskie przyjął w 1921 r. i zaczął duszpastersko pracować w orawskiej parafii Zazriwa. W rok później biskup Jan Vojtaššak powołał go do Seminarium w Spiskiej Kapitule i powierzył mu wykłady z filozofii chrześcijańskiej, które prowadził do roku 1944. W latach 1922-1927 był prefektem kleryków, od roku 1934 - wicerektorem Seminarium, które potem od roku 1938 do chwili śmierci prowadził jako jego rektor. Pod jego kierownictwem tak Seminarium jak i Instytut Teologiczny osiągnęły właściwy sobie rozwój. Jako chrześcijański filozof uprawiał tę dyscyplinę wiedzy jako neoscholastyk i neotomista. W oparciu o filozofię i teologię tomistyczną przeciwstawiał się dwom groźnym systemom - liberalizmowi i socjalizmowi. W walce z nimi odwoływał się do idei

\footnotetext{
„Wesz” albo „Wszy”.

7 „Kultura” 15 (1943) č. 3.
} 
osoby, osobowości i społeczeństwa. Na zasadach tomistycznego personalizmu sformułował też swoje zasady filozofii społecznej, aplikując je do ówczesnych konkretnych słowackich warunków. Z jego publikacji, które zainteresują patrologów, trzeba wymienić artykuł opublikowany w czasopiśmie „Kultura” 3 (1931) č. 5: Porovnanie sv. Augustina so sv. Tomášom Akvinským. Oprac. Jan Letz, LEKKOS, kol. 1243-1245.

g). Stipšič (Stipsics, Stipsitz) Franciszek (ur. 11.09.1745 - Stoličny Bělehrad, Węgry, zm. 02.04.1817 - Trnawa), archidiakon, uniwersytecki profesor. Studia filozoficzne i teologiczne odbywał w Trnawie, gdzie w roku 1763 uzyskał stopień bakałarza filozofii, a w rok później - magistra. W późniejszych latach uzyskał stopień doktora filozofii i teologii. W latach 1773-1777 w uniwersytecie trnawskim wykładał teologię i język grecki, a potem te same przedmioty (w latach 1773-1774) - w uniwersytecie budapeszteńskim, gdzie w tym samym czasie pełnił funkcję dziekana Wydziału Teologicznego. W latach 1804-1807 w Bratysławskiej Akademii Królewskiej powierzono mu funkcję prefekta studiów. Po powrocie do Trnawy, od roku 1807 pełnił funkcję rektora Seminarium i zastępcy dyrektora gimnazjum. Drukiem opublikowano jego kazanie: Panegyricus divo Aurelio August injo (Budapeszt 1778). Oprac. Vladimír Gregor, LEKKOS, kol. 1280.

h). Čapodi Ludwik (ur. 09.10.1729 - Pečeňady, powiat Piešt'any, zm. 06.06.1801 - Vesprém, Węgry) - jezuita, teolog. Do Towarzystwa Jezusowego wstąpił w Trnawie 14.10.1747 roku. Teologię studiował w uniwersytecie wiedeńskim (1755-1758). Uzyskał doktorat z filozofii i teologii. W latach 1766-1773 $\mathrm{w}$ uniwersytecie trnawskim prowadził wykłady $\mathrm{z}$ teologii, a jego znakomite dzieło o Bogu i Jego przymiotach ${ }^{8}$ należy do najobszerniejszych opracowań, jakie powstały w tutejszym zakładzie teologicznym. W tym i w innych swoich dogmatycznych opracowaniach ${ }^{9}$ wykorzystywał poglądy św. Augustyna i Tomasza z Akwinu. Oprac. Juliusz Slaný, LEKKOS, kol. 199.

i). Muška Stefan Franciszek (ur. 18.07.1924 - Nižná Šebastová, obecnie część Preszowa) minoryta, pisarz religijny. Nauki gimnazjalne pobierał w Preszowie, a potem w Malackách. Teologię studiował we Franciszkańskim Studium Generalnym w Żylinie. Po przyjęciu święceń kapłańskich (26.06.1949) aż do brutalnej likwidacji klasztorów (14.04.1950) pracował jako wikariusz w Malackach. Po powrocie z obozu (od 01.09.1950) pracował duszpastersko. W swoim studium poświęconym świętemu Bonawenturze ${ }^{10}$ podkreślał, że ten jako filozof i teolog stał na pograniczu dwóch okresów: rozpadającego się idealizmu platońsko-augustyńskiego i arystotelizmu. Św. Bonawentura, wed-

${ }^{8}$ Por. De Deo et divinis ejus attributis libri tres, Trnawa 1772.

${ }^{9}$ Por. De gratia Christi libri IV, Trnawa 1769; De augustissimis Trinitatis et Incarnationis misteriis libri duo, Trnawa 1772; De religione revelata, eius regulis et virtutibus praecipuis libri tres, Trnava 1771

${ }^{10}$ Por. Dielo sv. Bonaventúru, „Františkánský obzor” 10 (1944/1945) 67-72. 
ług niego, usiłował stworzyć własny - pośredni system myślowy, a w swoim dziele Hexameron przeciwstawiał się wyraźnie niektórym twierdzeniom Arystotelesa i Piotra Lombarda; nad filozofów zaś Arystotelesa i Platona przedkładał św. Augustyna. Oprac. Jan Letz, LEKKOS, kol. 967-968.

\section{BOECJUSZ}

a). Braničkovič Apolinary Leander, (ur. 28.02.1888 - Leopoldów, powiat Hlohovec, zm. 18.10.1956 - Subotica, Serbia) minoryta wychowawca, pisarz, kaznodzieja. Po ukończeniu szkoły podstawowej w rodzinnej miejscowości, od roku 1902-1905 uczęszczał do salezjańskiego gimnazjum w Cavaglia koło Turynu. W roku 1905 wstąpił do Zakonu minorytów (OFM). Studia filozoficzne odbył w Warażdinie, a teologiczne w Zagrzebiu, gdzie (13.08.1911) przyjął święcenia kapłańskie. Po krótkiej pracy duszpasterskiej (1911-1914) został profesorem Franciszkańskiego Seminarium Duchownego w Warażdinie (1914-1924). Powróciwszy do zdrowia po przebyciu poważnej choroby pracował w zakonnej administracji miejscowej, a później także - prowincjalnej. Swoje wybitne zdolności językowe wykorzystał jako tłumacz literatury religijnej i teologicznej z łaciny, greki, i z języków nowożytnych - węgierskiego i włoskiego. Z literatury starochrześcijańskiej przełożył na język chorwacki Boecjuszowe De consolatione philosophiae. Z ciekawej zaś twórczości papieża Grzegorza Wielkiego czytelnikowi chorwackiemu przybliżył jego Epistolae i Homiliae, a duchowieństwo otrzymało jego przekład traktatu św. Jana Złotoustego De sacerdotio. Oprac. Franciszek Vnuk, LEKKOS. kol. 144.

b). Illel Jan (ur. 03.05.1725 - Komarno, zm. 24.01.1794), jezuita pedagog, dramaturg, tłumacz. Do Towarzystwa Jezusowego wstąpił w Köszegu 17.10.1743, a po odbytym nowicjacie w Trenczynie (1745), przez najbliższe dwa lata w Skalicy, a potem w Gyöngyösi pracował jako wychowawca młodzieży. Studia filozoficzne (1748-1750) odbył w uniwersytecie trnawskim. Po ich ukończeniu uczył gramatyki w Gyöngyösi (1751) i w Klużi (1752) oraz retoryki w Eger (1753). Teologię studiował w Trnawie w latach 1754-1757. W Kluzi, jako profesor wykładał etykę i prawo kanoniczne (1761), w Budzie filozofię (1762-1763); dwukrotnie prowadził wykłady z apologetyki: w Rabe (1764) i w Koszycach (1766), a w latach 1767-1773 pełnił obowiązki rektora Seminarium w Klużi prowadząc przy tym wykłady z filozofii. Wśród jego przekładów, dokonanych w większości z francuskiego i łaciny, znalazły się również niektóre dzieła Boecjusza ${ }^{11}$ Oprac.: Juliusz Slaný. LEKKOS, kol. 561.

${ }^{11}$ Antizius Manlius Torquatus Severinus Boetzius V, Koszyce 1766. Przytoczony opis bibliograficzny, jak go przekazał autor opracowania, wydaje się niekompletny, dlatego też nie można w sposób pewny powiedzieć, czy jego przekład zawiera wszystkie dzieła Boecjusza, czy tylko niektóre. 


\section{5. ŚW. CYPRIAN z KARTAGINY}

a). Muška Antoni (ur. 03.02.1719 - Rybnik, powiat Lewice, zm. 21.04.1790 - Trnawa), jezuita. Do jezuitów wstąpił 17.10.1734 roku, a nowicjat odbywał w Trenczynie. Po jego ukończeniu studiował przez rok w Skalicy łacinę i retorykę (1737), a potem (1738-1744) w gimnazjach Wiednia, Trnawy, Koszyc i Klużi przedmioty humanistyczne, gramatykę i poetykę. Teologię studiował w Koszycach (1745-1748), z której uzyskał doktorat. Jako profesor jezuickich uniwersytetów wykładał: hebrajski - w Koszycach (1751), teologię i hebrajski w Trnawie (1752), nauki humanistyczne i prawo - w Rabe (1753-1754), nauki społeczne i fizykę - w Koszycach (1755-1756), pełniąc przy tym obowiązki dziekana Wydziału Językoznawstwa. Potem pracował jako profesor historii powszechnej i historii Kościoła w Sztajerskim Hradcu (1757), profesor filozofii, teologii, Pisma św. i prawa kanonicznego w Koszycach (1758-1763), będąc przy tym dziekanem Wydziału Nauk Etycznych. W latach 1764-1770 w uniwersytecie trnawskim pełnił funkcję jego kanclerza. Kasata zakonu zastała go na stanowisku przełożonego domu w Skalicy. Wydał Listy św. Cypriana ${ }^{12}$ i Homilie św. Jana Złotoustego ${ }^{13}$.

\section{6. ŚW. CYRYL JEROZOLIMSKI}

a). Hotka Wiliam (ur. 02.06.1915 - Wielka Mania, powiat Nowe Zamki, zm. 05.01.1995 - Turcziańskie Tieplice, powiat Martin), teolog, liturgista. Święcenia kapłańskie przyjął (26.06.1938) w Trnawie. Wikariuszowskie prace w czterech parafiach prowadził do roku 1941. Pierwszą parafią w Dubowej, jako jej proboszcz zarządzał do roku 1949. Tego samego roku został mianowany ojcem duchownym w trnawskim Wyższym Seminarium Duchownym oraz diecezjalnym cenzorem publikacji religijnych. Tę pracę prowadził do 1953 roku. Potem powrócił do pracy parafialnej, a jako proboszcz w latach 19531965 zarządzał kolejnymi czterema parafiami. Od roku 1965 był Sekretarzem Słowackiej Komisji Liturgicznej, a w 1968 r. został mianowany Rektorem Wyższego Seminarium Duchownego w Bratysławie, po czym od roku 1970 zarządzał parafią w Jasowej koło Nowych Zamków i w Labe (1979). Od roku 1992 do końca życia ponownie pracował w Seminarium jako ojciec duchowny. Mając ku temu szczególne dyspozycje, jako teolog zajmował się duchowością chrześcijańską, wykorzystując przy tym obficie wypowiedzi Ojców Kościoła: Leona Wielkiego, Cyryla Jerozolimskiego i Jana Złotoustego. Oprac. Jan Letz, LEKKOS, kol. 522.

12 Epistolae divi Caecilii Cypriani Carthaginensis episcopi auditoribus oblatae, Trnawa 1764.

13 Sancti Patris nostri Joannis Chrisostomi... homiliae de statutis ad populum Antiochenum habitae, Trnawa [brak roku wydania]. 


\section{7. ŚW. GRZEGORZ WIELKI}

a). Balog Mikołaj (ur. 1625 - Turiec, zm. 06.10.1689 - Spiska Kapituła, powiat Lewocza), biskup. Studiował w Trnawie, gdzie jako ewangelik nawrócił się na wiarę katolicką. Studia kontynuował w Rzymie w tamtejszym Kolegium niemiecko- węgierskim. Od czasu pozostania proboszczem, postępował w godnościach kościelnych, aż (w 1677 r.) stał się biskupem tytularnym. Potem objął diecezję Czanadską (1681) i rządził nią jako jej ordynariusz aż do chwili przeniesienia go na stolicę biskupią w Wacowie (1686). W pracy duszpasterskiej dał się poznać, jako gorliwy i wytrwały zwolennik rekatolizacji. W swoim dorobku pisarza religijnego pozostawił dwutomowe rękopiśmienne dzieło: Nucleus totius libri Job ex sancto Gregorio papa excerptus. Oprac. Włodzimierz Gregor, LEKKOS, kol. 51.

b). Braničkovič Apolinary Leander - autor chorwackiego przekładu Listów i Homilii papieża Grzegorza Wielkiego, zob. BOECJUSZ.

\section{8. ŚW. GRZEGORZ Z NAZJANZU}

a) Klement (ur. przed 836, zm. 27.07.918 - Ochrida w Macedonii), biskup, wielkomorawski hagiograf. O jego pochodzeniu nie wiemy nic pewnego. Specjaliści od historii Księstwa Wielkomorawskiego przypuszczają, że był Macedończykiem. Nie brakuje wśród nich jednak zwolenników poglądu, że pochodził z terenów należących do Księstwa Wielkomorawskiego. Należał do grona uczniów św. Cyryla i Metodego, misjonarzy wielkomorawskich. Święcenia kapłańskie przyjął w Rzymie w roku 868. Po śmierci św. Metodego i odejściu z Wielkich Moraw został nauczycielem w Ochrydzie, gdzie razem z Naumem, innym uczniem św. Metodego założyli starosłowiańską szkołę dla 350 ucznów. Kiedy książę Symeon w roku 893 zabezpieczył powstanie biskupstwa welickiego, pierwszym jego ordynariuszem został Klement. On też przełożył z języka greckiego na starosłowiański wierszowaną pieśń poetycką ku czci św. Grzegorza z Nazjanzu, której autorem z czasów swojej młodości był św. Cyryl. Oprac. Lubomir V. Prikryl, LEKKOS, kol. 673-674.

\section{9. ŚW. HIERONIM}

a). Akai (Akkay) Krzysztof (ur. 26.03.1706 - Sul'ov-Hradná, powiat Bytcza, zm. 28.03.1767 - Kláštor pod Znievom, pow. Martin), jezuita, filozof, pisarz religijny, przyrodoznawca. Do zakonu jezuitów wstąpił w Wiedniu 15.10.1723 roku. Nowicjat odbył w Komarnie w latach 1724-1725. W Sztąjerskim Hradc studiował filozofię (1726-1728). Po jej ukończeniu, uczył w Trnawie gramatyki (1729-1730), a potem przedmiotów humanistycznych w Bratysławie (1731). Następnie powrócił do Trnawy, gdzie w latach 1732-1735 studiował teologię. W szkole klasztornej w Gyöngyösi uczył filozofii i historii (1736). W jezuickim uniwersytecie koszyckim (1738-1744) wykładał filozofię i etykę. W roku 1741 
wydał drukiem Selectae divi Hieronymi epistolae in carminis materiam assumptae. Oprac. Juliusz Slaný, LEKKOS, kol. 9.

b). Oros (Orosz) Franciszek (ur. 1697 - Wielkie Ulany, powiat Galanta, zm. 11.09.1771 - Trebiszów), paulin, pisarz religijny, tłumacz. Do zakonu paulinów wstąpił w roku 1714. Pracował w wielu paulińskich klasztorach. W klasztorze Marianostre (Węgry) był magistrem nowicjuszy (1747). Większość jego prac pozostała w rękopisie. $Z$ wydanych drukiem trzeba odnotować: 1) Vita sancti Pauli primi eremitae authore D[ivo] Hieronymo praesbytero et Ecclesiae Doctore, w: Oros Franciscus, Synopsis annalium coenobiticorum FF.[ratrum] Eremitarum ordinis S[ancti] Pauli primi eremitae... concinnata, Sopron 1747. 2) Szent Jeronimus, Sopronii 1754. Oprac. Włodzimierz Gregor, LEKKOS, kol. 1019.

\section{0. ŚW. IGNACY ANTIOCHEŃSKI}

a). Čižmár Marian (ur. 01.11.1953 - Belá nad Cirochou, powiat Snina), historyk, pisarz religijny. Szkołę podstawową ukończył w Sninie i tam też złożył egzamin dojrzałości (1971). Teologię studiował na Cyrylo-metodejskim Wydziale Teologicznym uniwersytetu bratysławskiego (1971-1976) i w krakowskiej Papieskiej Akademii Teologicznej (1992-1996), gdzie też w roku 1998 uzyskał doktorat z teologii. Święcenia kapłańskie przyjął 06.06.1976 r. w Bratysławie. Należy do duchowieństwa archidiecezji koszyckiej. Jako wikariusz w latach 1976-1982 pracował kolejno w parafiach: Jankowce, Humenné, Zborów, Wranów nad Toplą i Trebiszów. Samodzielnie, jako administrator parafii pracował w Ohradzanach (1984), w Niżnym Medzewie (1988) i w Wysznym Klatowie (1990), a jako proboszcz - w Stropkowie (1990) i w Rażnianach (1994). W latach 1990-1991 był członkiem Rady Kapłańskiej i Kolegium Konsultorów Diecezjalnych. Pełnił też przy tym funkcję osobistego sekretarza biskupa koszyckiego i notariusza Diecezjalnego Sądu Biskupiego. W latach 1992-1994 był tam także Promotorem Sprawiedliwości. Od roku 1991-1996 był ojcem duchownym alumnów Centralnego Wyższego Seminarium Duchownego w Spiskiej Kapitule i asystentem przy Katedrze Teologii Życia Wewnętrznego Instytutu Teologicznego w Spiskiej Kapitule. Z tego okresu pracy w seminarium pochodzą jego opracowania poświęcone wybitnym postaciom w historii duchowości i doskonałości chrześcijańskiej, jak św. Augustyn i św. Ignacy Antiocheński. Brak im jednak dokładnej dokumentacji bibliograficznej. W roku 1997 opublikował pracę: Sv. Ján Chryzostom a jeho pohl'ad na kñazstvo. Odchodząc z diecezji koszyckiej, w roku 1995-1996 w Nitrze, a później w Rzymie, odbył nowicjat w zakonie pijarów. Od roku 1996-1999 pracował jako archiwista Kurii Arcybiskupiej w Koszycach, a od roku 2000 pełni obowiązki administratora parafii w Niżnym Hruszowie. Oprac. Paweł Kollár, pijar, LEKKOS. 


\section{1. ŚW. JAN ZŁOTOUSTY}

a). Spišák Pawel (ur. 28.06.1901 - Telgart, powiat Březno, zm. 17.03.1975 Telgart), publicysta, prześladowany za wiarę, tłumacz. Podstawowe wykształcenie zdobywał $\mathrm{w}$ miejscowości narodzenia i na dworze bułgarskiego cara Borysa. Gimnazjum ze świadectwem maturalnym (1921) ukończył w Keżmarku. Jeden rok studiował w Seminarium Nauczycielskim w Preszowie, a po przeniesieniu się do Grekokatolickiego Instytutu Teologicznego, ukończyl tam studia w latach 1923-1927. Bezżenny przyjął 28.08.1927 r. święcenia kapłańskie. Pierwszą placówką duszpasterską była parafia w Wysznej Jabłonce. W latach 1928-1935 i 1939-1951 prowadził parafię Vernar (powiat Poprad). Czas między odejściem i powrotem do parafii spędził na pracy duszpasterskiej w Toryskach (powiat Spiska Nowa Wieś). Przy likwidacji Kościoła Greckokatolickiego w Słowacji (1950) nie podpisał żądanego przejścia na prawosławie i nie chciał opuścić swojej parafii. W nocy z 15 na 16.08. 1951 r. przemocą został schwytany i internowany w Hlochowcu i Podolincu. W listopadzie tegoż roku został skazany na wygnanie do czeskiego Duchcowa. Po poważnej chorobie i wyzdrowieniu powrócił do Słowacji i przebywał w Bratysławie, a od roku $1953 \mathrm{w}$ rodzinnym Telgarcie. Wśród grekokatolików słowackich jest znany ze swojego, pierwszy raz dokonanego przekładu na język słowacki Božskej liturgie sv. Jána Zlatoústého. [B.r.]. Oprac. Jan Babjak, jezuita, LEKKOS, kol. 1268.

b). Branickovič Apolinary Leander, minoryta - tłumaczył na język chorwacki dialog Jana Złotoustego De sacerdotio, zob. BOECJUSZ.

c). Cižmár Marian - opracował poglądy Jana Złotoustego na kapłaństwo w pracy publikowanej w języku słowackim: Sv. Ján Chryzostom a jeho pohl'ad na kñazstvo, Prešov 1997, zob. IGNACY ANTIOCHEŃSKI.

d). Fedor Michal (ur. 25.04.1929 - Slanskie Nowe Miasto, powiat Koszyce, zm. 14.07.1994 - Koszyce), jezuita, profesor, bibliograf. Do szkoły podstawowej uczęszczał w Trebiszowie, a ukończył ją w 1944 roku. Potem, w latach 1945-1948 uczęszczał do Gimnazjum Kupieckiego w Koszycach. Egzamin dojrzałości jako eksternista złożył w roku 1949. W preszowskiej Grekokatolickiej Akademii Teologicznej ukończył trzy semestry. Do nowicjatu Towarzystwa Jezusowego wstąpił w Rużomberku dnia 01.03.1950 roku, a odbył go podczas kolejnego przebywania w obozach koncentracyjnych dla zakonników w Jasowie, Podolincu, Pezinku i Trnawie. Śluby zakonne złożył na początku marca 1952 r. w Beluskich Slatinách. Studiował na Wydziale Filozoficznym uniwersytetów bratysławskiego, a potem praskiego. Studia ukończył w 1956 roku i zaczął pracować w Maticy Słowackiej w Naukowej Bibliotece Państwowej w Koszycach i Słowackiej Akademii Nauk w Bratysławie. Za swoją aktywność religijną, zwłaszcza wśród grekokatolików, był pozbawiony pracy, a potem długo śledzony przez milicję. Tajnie kontynuował 
studia filozoficzne i teologiczne, które zakończył nieoficjalnym przyjęciem święceń kapłańskich w dniu 28.08.1961 roku. Doktorat z filozofii wraz z tytułem kandydata nauk uzyskał w roku 1969. Licencjat z teologii, ze specjalnością w teologii dogmatycznej, uzyskał w Papieskim Instytucie Teologicznym w Warszawie w roku 1992. W styczniu 1994 r. odbyło się kolokwium habilitacyjne a na podstawie rozprawy: Cirilometodska tradícia $w$ slovenskej literatúre a kultúre, przedłożonej Radzie Wydziału Filozoficznego koszyckiego Uniwersytetu Pawła Józefa Šafárika z siedzibą w Prešowie nadano mu tytuł docenta. Na Wydziale Filozoficznym bratysławskiego Uniwersytetu Komeńskiego prowadził zajęcia z informatyki i bibliografii specjalnej. W Instytucie Teologicznym św. Alojzego w Bratysławie i w Instytucie Teologicznym w Spiskiej Kapitule prowadził zajęcia z metodyki pracy naukowej. Przebywając w jezuickiej Wspólnocie koszyckiej, od roku 1990 zaczął organizować kontaktowe centrum chrześcijan Wschodu i Zachodu. Na tych fundamentach w 1997 r. wyrosło Centrum Duchowości Wschód - Zachód. W bogatym dorobku naukowym $\mathrm{z}$ dziedzin bibliografii, informatyki, historii Kościoła, cyrylometodejskiej tradycji słowackiej, patrolog może znaleźć nowy słowacki przekład: Liturgia sv. Jána Zlatoústeho (Koszyce 1968). Oprac. Jan Babjak, jezuita, LEKKOS, kol. 325-327.

e). Muška Antoni, jezuita - wydawca wyboru homilii św. Jana Złotoustego, opublikowanego w Trnawie [B.r.], zob. CYPRIAN z KARTAGINY

f). Hotka Wiliam - jako teolog i liturgista, w swoich pracach wykorzystał niektóre dzieła św. Jana Zlotoustego. zob. CYRYL JEROZOLIMSKI.

b). Lacko Michal (ur. 19.01.1920 - Krasna nad Hornadom, obecnie miejska część Koszyc, zm. 21.03.1982 - Rzym), jezuita, grekokatolicki profesor rzymskich uniwersytetów, pisarz religijny. Po ukończeniu gimnazjum w Koszycach (1930-1938) wstąpił do jezuitów. Nowicjat i studia studia filozoficzne odbywał w Zagrzebiu (1938-1942). W roku 1945 udał się do Rzymu na czteroletnie studia teologiczne i filozoficzne, które ukończył w Papieskim Uniwersytecie Gregoriańskim i w rzymskim uniwersytecie La Sapienza. Święcenia kapłańskie w obrządku bizantyjskim przyjął 6.5. 1948 roku. Od roku 1949 poświęcił się studiom historii Kościoła powszechnego i Kościoła Wschodniego, w czym były mu bardzo pomocne studyjne kontakty z Papieskim Instytutem Wschodnim (1950-1954). W roku 1953 w Uniwersytecie La Sapienza przedłożył swoją pracę: Papeži a Vel'ká Morava v 9. storoči vo světle dokumentov pápežskej kúrie, na podstawie której uzyskał doktorat. W dwa lata później na Uniwersytecie Gregoriańskim złożył dalszą pracę: Užhorodská linia karpatských Ruténov s katolíckou Cirkvou i na jej podstawie uzyskał drugi doktorat (1955). W tym samym roku zaczął dydaktyczne zajęcia w Papieskim Instytucie Wschodnim obierając sobie jako specjalizację historię Kościoła na Bałkanach. Obok bardzo bogatego i specjalistycznego dorobku pisarskiego, razem z Feliksem Litvą ma swój duży udział w przygotowaniu modlitw w duchu 
Liturgii św. Jana Złotoustego: Nesmierny Bože, sláva Tebe, Paderborn 1960. Oprac. Jan Babják, jezuita, LEKKOS, kol. 794-795.

h). Litva Feliks (ur. 11.05.1919 - Mikszowa koło Bytczy), jezuita, uniwersytecki profesor, publicysta, działacz narodowy i kulturalny. Szkołę podstawową i część średniej ukończył w Trnawie. W roku 1934 wstąpił do Towarzystwa Jezusowego. Nowicjat odbywał w Rużomberku. Świadectwo dojrzałości zdobył w miejscowości Klasztor pod Zniewom (1938). Filozofię do roku 1941 studiował w Beneszowie koło Pragi, a teologię od roku 1942 w Banskej Bystrzycy. Święcenia kapłańskie przyjął 25.01 .1945 roku. W bratysławskim uniwersytecie od roku 1946 studiował historię i filologię francuską. W kwietniu 1950 r. razem z innymi zakonnikami był internowany w Jasowie, a później w Podolińcu. Należał do grupy ośmiu jezuitów, którzy w przypadku, gdy prowincjał nie będzie mógł pełnić swojej funkcji przełożonego, mieli podjąć się jego obowiązków. W lecie 1950 r. udało mu się wydostać z klasztoru koncentracyjnego. Od tej chwili ukrywał się na Morawach, aż do chwili, kiedy w lecie 1951 r. mógł przekroczyć granicę i znaleźć się na Zachodzie. W latach 1951-1952 pracował w słowackiej sekcji Radia Watykańskiego. Studiował też teologię życia wewnętrznego (1952-1953), a później na Uniwersytecie Gregoriańskim w latach 1953-1957 historię Kościoła. Studia uwieńczył doktoratem, po którego osiągnięciu, ze strony uczelnianych władz Uniwersytetu Gregoriańskiego, dostał propozycję wykładania historii watykańskiej administracji. Równocześnie wykładał w Watykańskiej Szkole Archiwoznawstwa i Bibliotekoznawstwa archiwistykę. W roku 1968 został wybrany wiceprowincjałem zagranicznych jezuitów słowackich. Osiadł wtedy w Cambridge Ont. w Kanadzie, gdzie rozwinął bardzo szeroką i aktywną działalność duchowną i kulturalną wśród Słowaków na obczyźnie. Od roku 1974 i dla niego znalazło się miejsce w Światowym Kongresie Słowackim, które zajął i wykorzystał dla prawdziwego dobra emigracji słowackiej. W trosce o utrzymanie i rozwój duchowości słowackich grekokatolików na obczyźnie, w wyniku współpracy z o. Michałem Łącko SJ, opublikował w roku 1960 w Paderborn zbiór modlitw: Niesmierny Bože, sláva Tebe, zredagowanych w duchu Liturgii św. Jana Złotoustego. Po śmierci o. M. Łącko, od roku 1982 przejął i kontynuował wydawanie rocznika „Slovák Studies". W roku 1990 powrócił do Słowacji i bardzo aktywnie włączył się do pracy nad odnowieniem i rozwojem wydawnictwa jezuickiego. Miał też wielki udział w utworzeniu Uniwersytetu w Trnawie (1992), którego był prorektorem. Oprac. Franciszek Vnuk, LEKKOS, kol. 828-830.

\section{SW. JUSTYN}

a). Príleský (Prileszky) Jan (ur. 16.03.1709 - Trenczianska Tiepla-Priles, pow. Trenczyn, zm. 27.10.1790 - Priles), jezuita, uniwersytecki pedagog, pisarz barokowy. Do jezuitów wstąpił 09.10.1724 r. w Trenczynie, gdzie też odbywał nowicjat (1725-1726). W Leobene studiował nauki społeczne (1727). W niż- 
szych klasach ostrzyhomskiego gimnazjum uczył gramatyki (1728). W trnawskim uniwersytecie (1729) rozpoczynał studia filozoficzne, które dokończył w Sztajerskom Hradci (1731). W gimnazjach Rabe (1732) i Koszyc (17331734) ponownie poświęcił się pracy dydaktycznej ucząc w nich gramatyki i zaznajamiając swoich uczniów z tematyką nauk społecznych. Teologię studiował w Wiedniu (1735-1738), a w Sztajerskim Hradcu prawo kanoniczne (1739). Po uzyskaniu doktoratu z filozofii i teologii, w latach 1741-1744 na uniwersytecie trnawskim prowadził wykłady z filozofii. Wykładał również apologetykę w Sztajerskim Hradcu (1745-1746) oraz nauki biblijne i teologię w Trnawie (1747-1759). W Wiedniu w latach $1760-1762$ był rektorem słynnej uczelni teologicznej Pazmaneum. Po swoim powrocie do Trnawy, w latach 1763-1764 pełnił obowiązki kanclerza tamtejszego uniwersytetu i prefekta biblioteki uniwersyteckiej. Po przybyciu do Koszyc, w latach 1765-1766 jako prefekt prowadził drukarnię akademicką, a w latach 1771-1773 stał na czele tamtejszego uniwersytetu jako jego rektor. Po likwidacji zakonu jezuitów osiadł w Trenczynie, gdzie jako nauczyciel pomagał uczyć pijarom, w ich własnym gimnazjum. W całokształcie działalności Jana Prileskiego trzeba również dostrzec jego wkład w upowszechnienie dzieł Ojców Kościoła. Przedmiotem jego badań i zainteresowań wydawniczych byli: św. Justyn, apologeta, papież Korneliusz i papież Leon Wielki. Do jego publikacji w tej dziedzinie należą: Sancti Justini philosophi et martyris acta et scripta (Koszyce 1765-1766) i Acta et scripta s. Cornelii (Koszyce 1765), które ukazały się w czasie, kiedy jako wydawca zarządzał akademicką drukarnią w Koszycach. Dzieła zaś papieża Leona Wielkiego: Leonis I papae cognomento Magni opera omnia (1766) zostały wydane w Budapeszcie. Oprac. Lubosz Kačírek. LEKKOS, kol. 1121-1122.

\section{3. ŚW. KORNELIUSZ, papiez}

a). Príleský Jan, wydawca, zob. JUSTYN.

\section{4. ŚW. LEON WIELKI, papież}

a). zob. jak wyżej.

\section{MINUCJUSZ FELIKS}

a). Jego apologię Octavius, przełożył na język słowacki i wydał Jan MARKO, zob. AUGUSTYN.

\section{ORYGENES}

a). Jan $z$ Keżmarku (Jonnes de Kesmarckt - XV w. Keżmarok), teolog. Pochodził z Keżmarku, a studiował na zagranicznych uniwersytetach. Swoją uwagę skupił na biblistyce, filozofii i homiletyce. W 2. poł. XV wieku był proboszczem we Wrbowie, a następnie w Spiskich Wlachach. Opracował 
i pozostawił po sobie dwa dzieła: summę thologiczną Tractatus theologicus i Spiski kodeks z roku 1467-1472, zawierający w sobie kompendia teologiczne, homilie i antologie z pism św. Tomasza z Akwinu i Orygenesa oraz dzieło św. Anzelma: Cur Deus homo. Oprac. Iwan Chalupecký, LEKKOS, kol. 587.

Leander Tadeusz Pietras OSPPE Vranov nad Topl'ou, Słowacja 